\title{
PENGARUH KEMANDIRIAN BELAJAR, MINAT BACA DAN KECERDASAN NATURALIS TERHADAP PRESTASI BELAJAR BIOLOGI
}

\author{
Dita Kameswari \\ Jurusan Pendidikan Biologi, Fakultas MIPA, Universitas Indraprata PGRI \\ Email: dita.kameswari2528@gmail.com
}

\begin{tabular}{l}
\hline Tersedia Online di \\
http://www.jurnal.unublitar.ac.id/ \\
index.php/briliant
\end{tabular}

\section{Sejarah Artikel}

Diterima pada 14 Maret 2019

Disetuji pada 20 Maret 2019

Dipublikasikan pada 22 Mei 2019

Hal. 132-141

\section{Kata Kunci: \\ Kemandirian Belajar, Minat \\ Baca, Kecerdasan Naturalis dan \\ Prestasi Belajar Biologi}

DOI:

http://dx.doi.org/10.28926/briliant .$v 3 \mathrm{i} 4.283$

biologi siswa SMAN Kecamatan Rangkasbitung. Dengan demikian prestasi belajar biologi dapat ditingkatkan melalui kemandirian belajar, minat baca dan kecerdasan naturalis.

\begin{abstract}
Abstrak: Tujuan dari penelitian ini adalah untuk menganalisis dan menguji kebenaran hipotesis mengenai Pengaruh Kemandirian Belajar, Minat Baca dan Kecerdasan Naturalis terhadap Prestasi Belajar Biologi. Metode dalam penelitian ini adalah survei. Teknik analisis data yang digunakan dalam penelitian ini adalah teknik korelasi dan model analisis regresi linier berganda. Hasil analisis diperoleh koefisien korelasi sebesar 0,957 dan koefisien determinasi sebesar 91,5\%, serta Hasil analisis data menggunakan persamaan regresi parsial diperoleh $\widehat{Y}$ $=-27,586+0,181 X_{1}+0,100 X_{2}+0,346$. Hasil pengujian hipotesis diperoleh kesimpulan sebagai berikut: 1) terdapat pengaruh yang signifikan kemandirian belajar, minat baca dan kecerdasan naturalis terhadap prestasi belajar biologi siswa SMAN Kecamatan Rangkasbitung. 2) terdapat pengaruh yang signifikan kemandirian belajar terhadap prestasi belajar biologi siswa SMAN Kecamatan Rangkasbitung. 3) terdapat pengaruh yang signifikan minat baca terhadap prestasi belajar biologi siswa SMAN Kecamatan Rangkasbitung, 4) terdapat pengaruh yang signifikan kecerdasan naturalis terhadap prestasi belajar
\end{abstract} PENDAHULUAN

Pendidikan adalah usaha sadar dan sengaja serta terorganisir guna meningkatkan pengetahuan, ketrampilan dan sikap serta peruhahan-perubahan tingkah laku yang diharapkan sesuai dengan tujuan pendidikan yang dicanangkan sebelumnya, baik ini tujuan kurikulum, institusional, maupun nasional. Dalam Undang Undang RI No. 20 tahun 2003 tentang Sistem Pendidikan Nasional memuat bahwa: Pendidikan Nasional berfungsi mengembangkan kemampuan dan membentuk watak serta peradaban bangsa yang bermartabat dalam rangka mencerdaskan kehidupan bangsa, dan bertujuan untuk mengembangkan potensi siswa agar menjadi manusia yang beriman dan bertaqwa kepada Tuhan Yang Maha Esa, berakhlak mulia, sehat, berilmu, cakap, kreatif, mandiri dan menjadi warga negara yang demokratis serta bertanggung jawab. Untuk mencapai tujuan nasional tersebut diperlukan adanya pendidik yang professional, keberadaanya dalam dunia pendidikan baik bersifat formal maupun non formal berupaya untuk mengembangkan segala potensi sumber daya manusia secara totalitas (intelektual, rasional, perasaan, cipta dan karya manusia), sehingga siswa dapat mengetahui betul akan potensi yang dimilikinya. Oleh karena itu peranan pendidik sangat penting, artinya dalam proses belajar mangajar seorang pendidik 
mempunyai tanggung jawab dalam menentukan tujuan pendidikan.

Masalah kualitas pendidikan merupakan salah satu masalah yang krusial di bidang pendidikan yang sedang dihadapi oleh negara-negara berkembang termasuk Indonesia, diantaranya masalah kuantitas, efektivitas, efisiensi, dan relevansi. Sudah banyak upaya yang dilakukan oleh pemerintah untuk mengatasi masalah-masalah tersebut di atas. Namun upaya-upaya tersebut masih bersifat umum dan global, belum menyentuh masalah-masalah yang langsung dihadapi di dalam kelas. Memang disadari, bahwa sebaiknya apapun kurikulum pendidikan yang disiapkan, jika tidak diimplementasikan dengan tepat dan benar oleh guru dan siswa di dalam kelas, maka tidak akan memberikan hasil optimal. Komponen guru dan siswa merupakan ujung tombak yang sangat menentukan keberhasilan proses belajar mengajar di kelas. Guru merupakan pengarang skenario sekaligus sutradara yang mengatur jalannnya proses belajar mengajar, tennasuk menyiapkan rencana pengajaran dengan mempertimbangkan kurikulum, sarana dan prasarana yang ada. Sedangkan siswa merupakan aktor yang memiliki kemampuan, motivasi, dan kesiapan yang memadai untuk mengikuti proses belajar mengajar di kelas.

Perubahan pesat, cepat dan luar biasa yang terjadi dalam berbagai segi ilmu pengetahuan, teknologi, budaya dan propesi merupakan ciri dari apa yang akan berlangsung di masa depan. Perubahan dan perkembangan berbagai aspek kehidupan perlu direspon oleh kinerja pendidik yang professional dan bermutu tinggi. Mutu pendidikan yang demikian diperlukan untuk mendukung tercapainya manusia yang cerdas dan berkehidupan damai, terbuka, dan berdemokrasi, serta mampu bersaing secara terbuka di era global. Pendidikan biologi akan memainkan peran penting untuk mempersiapkan individu dan masyarakat dalam mengantisipasi perubahan tersebut. Untuk mengembangkan prestasi belajar biologi yang sesuai dengan tuntutan era penuh perubahan tersebut, maka harus dikembangkan pembelajaran biologi yang tidak hanya mentranster pengetahuan kepada siswa tetapi juga membantu peserta didik untuk mencerna dan membentuk pengetahuan mereka sendiri serta memberdayakan mereka untuk memecahkan masalah-masalah yang dihadapinya. Pembelajaran biologi yang demikian tidak mungkin dapat dicapai hanya melalui hafalan, latihan pengerjaan soal serta proses pembelajaran yang berpusat pada guru. Sebagai tenaga professional tenaga pendidik akan dapat menggali, membina, mengarahkan, dan mengembangkan bakat serta potensi peserta didik, sehingga dapat bermanfaat bagi dirinya dan masyarakatnya. Dalam perkembangan selanjutnya seorang guru professional akan menciptakan suasana belajar yang menyenangkan dan mengasyikan. Anak didik akan sanggup bertahan lama dalam kelas tanpa merasa bosan untuk mengikuti pelajaran dengan baik.

Biologi merupakan pengetahuan yang diperlukan oleh peserta didik di setiap jenjang pendidikan untuk menunjang keberhasilan belajarnya dalam menempuh pendidikan yang lebih tinggi. Karena biologi merupakan suatu medan eksplorasi dan penemuan, sehingga dapat digunakan untuk memecahkan semua jenis persoalan di dalam sains, pemerintahan, dan industri. Oleh karena itu, perlu bagi para siswa menguasai biologi dan menerapkannya dalam memecahkan berbagai masalah. Mengingat pentingnya biologi, maka sangat diharapkan siswa sekolah menengah untuk mengusai pelajaran biologi SMA. Karena disamping biologi sebagai sarana berpikir ilmiah yang sangat diperlukan oleh siswa, juga 
untuk mengembangkan kemampuan berpikir logikanya. Biologi juga diperlukan untuk menunjang keberhasilan belajar siswa dalam menempuh jenjang yang lebih tinggi.

Banyak siswa yang menganggap biologi adalah mata pelajaran yang sangat sulit, menjemukan, hanya berkait dengan bacaan, hanya berkait dengan kegiatan menghafal, dan lain sebagainya. Sudah menjadi gejala umum bahwa mata pelajaran biologi kurang disukai oleh siswa baik tingkat dasar maupun tingkat lanjutan. Tidak dipungkiri kebanyakan dari gurupun mempunyai pengalaman tidak menyenangkan sewaktu mempelajari biologi di SMP atau SMA.Kenyataan ini tidak jarang berubah menjadi kebencian terhadap apa saja yang berhubungan dengan biologi. Bahwasannya biologi tidak disenangi di masyarakat, antara lain ditunjukkan oleh sikap sebagian besar masyarakat yang phobia terhadap biologi. Sebagian masyarakat menganggap biologi kurang bermanfaat dalam kehidupan bermasyarakat. Tidak jarang timbul pertanyaan apa manfaat biologi dalam kehidupan sehari-hari. Tapi itu tidak berarti bahwa kita boleh menjatuhkan keputusan bahwa biologi hanya boleh diketahui oleh sekumpulan orang tertentu saja. Contoh secara tidak langsung dengan biologi, seorang dokter bedah akan sangat membantu untuk menentukan letak organ tubuh bagian dalam diri seorang pasiennya (Budiarto, 2004:56).

Sistem belajar yang menyamaratakan kemampuan peserta didik, saat peserta didik belum menguasai materi dasar, sudah ditambah dengan materi lain. Apalagi jika guru yang mengajar biologi sulit dipahami dalam menyampaikan materi di dalam kelas, sehingga keadaan ini menambah ketidaksukaan peserta didik pada biologi, minat baca menurun dan bahkan akhirnya membenci gurunya. Untuk itu, minat baca materi biologi harus ditingkatkan dengan memperhatikan tingkat pemahaman peserta didik dan harus diberikan dengan jelas, praktis atau semenarik mungkin. Hal ini dihadapkan dapat membangkitkan kesukaan peserta didik pada biologi, karena pada dasarnya seseorang yang membenci tidak akan dapat mempelajari dengan baik apa yang dibencinya, Pemilihan metode mengajar, penggunaan alat bantu pengajaran, suasana lingkungan kelas dan faktor-faktor lain harus diatur sedemikian rupa sehingga membangkitkan semangat atau motivasi siswa mempelajari biologi. Di sekolah, siswa selalu dihadapkan pada situasi penilaian keberhasilan, baik dan guru maupun dari siswa lain. Situasi penilaian yang dihadapi peserta didik bukan hanya penilaian selama ulangan atau ujian saja, tetapi juga dari keberhasilan peserta didik dalam melaksanakan seluruh tugas sekolah. Sepanjang waktu sekolah, peserta peserta didik dapat menilai dirinya sendiri maupun peserta didik lainya dengan cara melihat bagamana ia atau peserta didik lain menyelesaikan tugas yang diberikan. Glasser (Tarmidi, 2008) dalam bukunya school without failure, mengemukakan bahwa sesungguhnya seluruh aspek kehidupan dalam masyarakat selalu merupakan dikotomi antara "gagal dan berhasil". Konsep biologi yang gagal dan berhasil itu dijadikan sandaran menilai pelaksanaan tugas, serta dalam menyusun sikap dan pandangan terhadap kemampuan biologi yang berkaitan dengan kecerdasan naturalis yang merupakan kemampuan untuk mengenali, membedakan, mengungkapkan, dan membuat kategori terhadap apa yang dijumpai di alam maupun lingkungan termaksud mengklasifikasikan berbagai spesies flora dan fauna.

Situasi ketika peserta didik melaksanakan seluruh tugas dengan bersandar 
pada keberhasilan dan kegagalan pada masa lampau harus dimanfaatkan guru untuk membimbing siswa agar selalu berusaha mencapai keherhasilan. Bimbingan tersebut dapat berupa pemberian gambaran positif tentang keberhasilan yang telah dicapai siswa. Gambaran positif ini dilakukan dengan memperlihatkan hasil belajar siswa dari waktu ke waktu secara lengkap, sehingga siswa memperoleh gambaran kemajuannya selama jangka waktu tertentu. Selain itu juga guru harus sadar bahwa keberhasilan kecerdasan naturalis yang dicapai tergantung dari keberhasilan dan usahanya, bukan karena faktor kebetulan dan keberuntungan saja. Sistem nilai yang ditekankan dalam dunia pendidikan adalah prestasi belajar. Prestasi belajar ini selanjutnva dijadikan patokan perilaku yang harus dicapai peserta didik. Penetapan peserta didik sebagai patokan perilaku, membuat guru selalu berusaha agar peserta didik mencapai patokan tersebut, dan tidak semua peserta didik berhasil mencapai prestasi belajar yang ditetapkan. Peserta didik yang berhasil mencapai prestasi belajar yang ditetapkan (kesuksesan), akan dipandang sebagai siswa yang mempunyai kemampuan dan usaha yang tinggi oleh guru dan peserta didik lain. Sebaliknya, peserta didik yang tidak berhasil (gagal) mencapai prestasi yang telah ditetapkan akan dipandang sebagai peserta didik yang tidak/kurang mempunyai kemampuan dan usaha.

Hampir setiap orang menggantungkan harapan kepada pendidikan untuk melahirkan generasi-generasi muda yang menguasai beragam ilmu dan pengetahuan, yang mampu memanfaatkan potensi diri dan setiap peluang dan pada akhirnya menjadi manusia-manusia yang sukses dalam setiap hal. Pendidikan seakan-akan menjadi syarat mutlak sebuah kesuksesan. Namun pada kenyataannya, terkadang seseorang berhasil mencapai jenjang pendidikan yang tinggi tetapi kurang berhasil dalam kehidupan, atau sebaliknya, tak jarang seseorang suskes dalam kehidupan, tetapi pencapaian akademiknya biasabiasa saja. Fenomena ketidak konsistenan antara pendidikan dan keberhasilan kehidupan tersebut memunculkan pertanyaan bagaimana sistem pendidikan yang sangat kompetitif ternyata dapat melahirkan generasi yang tangguh secara keilmuan tetapi rapuh atau gagal dalam kehidupan. Salah satu kemungkinan penyebabnya adalah ketika anak didik dihadapkan kepada beban pendidikan yang terlalu banyak dan ekspetasi yang terlalu tinggi dikarenakan lingkungan yang sangat kompetitif, sistem pendidikan dan Lingkungan tidak memberikan ruang yang cukup untuk mengembangkan kemandirian belajar anak didik secara matang dan positif.

Melihat kenyataan yang ada, ternyata tidak sedikit peserta didik yang merasa kesulitan menyelesaikan masalah biologi. Kejadian tersebut bisa terjadi karena banyak faktor antara lain: kemandirian belajar, minat baca dan kecerdasan naturalis, peserta didik dalam memahami keabstrakan biologi, kemampuan peserta didik dalam memahami konsep dan mengkomunikasikan biologi dalam mencari pemecahan masalah biologi masih rendah. Karena keterbatasan peneliti dalam melakukan penelitian, peneliti hanya mengambil salah satu faktor kesulitan peserta didik dalam menyelesaikan soal-soal biologi, yaitu kecerdasan naturalis peserta didik dalam memahami keabstrakan.

Berdasarkan pada pemikian tersebut, maka penulis tertarik untuk meneliti lebih lanjut tentang"Pengaruh Kemandirian Belajar, Minat Baca dan Kecerdasan Naturalis terhadap Prestasi Belajar Biologi Pada Siswa SMA Negeri di 
Kecamatan Rangkasbitung.

\section{METODE}

Penelitian dilakukan pada siswa kelas XI SMA Negeri di Kecamatan Rangkasbitung yang melibatkan 3 sekolah yaitu SMA Negeri 1 Rangkasbitung, SMA Negeri 2 Rangkasbitung, SMA Negeri 3 Rangkasbitung pertengahan semester ganjil tahun akademik 2017/2018. Penelitian ini berlangsung selama 5 bulan, yaitu dari bulan September 2017 sampai Januari 2018. Metode dalam penelitian ini adalah survei dengan menggunakan teknik analisis korelasional dan regresi. Desain penelitiannya dapat digambarkan sebagai berikut:

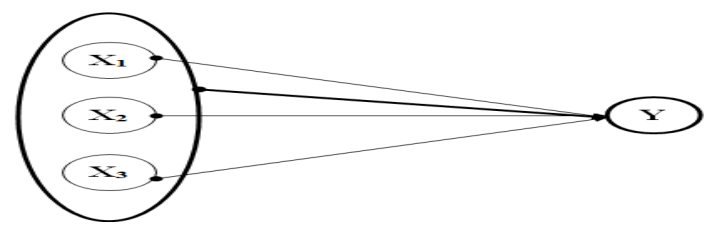

Gambar 1 Desain Penelitian

Keterangan :

$\mathrm{X} 1=$ Kemandirian Belajar

$\mathrm{X} 2=$ Minat Baca

$\mathrm{X} 3=$ Kecerdasan Naturalis

$\mathrm{Y}=$ Prestasi Belajar Biologi

Teknik sampling yang digunakan dalam penelitian ini adalah dengan menggunakan probability sampling dengan teknik simple random sampling. Teknik pengumpulan data untuk variabel kemandirian belajar, minat baca dan kecerdasan naturalis menggunakan angket yang di isi oleh siswa dan untuk variabel prestasi belajar biologi menggunakan nilai test. Dalam penelitian ini yang menjadi populasi adalah siswa kelas XI IPA SMAN 1, SMAN 2 dan SMAN 3 Rangkasbitung yang berjumlah 501 siswa dan diperoleh sampel sebanyak 60 siswa.

\section{HASIL DAN PEMBAHASAN}

\section{Deskripsi Data}

Tabel 1. Rekapitulasi Hasil Perhitungan Statistik Deskriptif

\section{Statistics}

\begin{tabular}{|l|r|r|r|r|}
\hline & $\begin{array}{c}\text { Kemandirian } \\
\text { Belajar }\end{array}$ & Minat_Baca & $\begin{array}{c}\text { Kecerdasan_ } \\
\text { Naturalis }\end{array}$ & $\begin{array}{c}\text { Prestasi_Belaja } \\
\text { r_Biologi }\end{array}$ \\
\hline Mean & 132,48 & 137,54 & 16,60 & 15,82 \\
Median & 133,50 & 138,00 & 19,00 & 17,50 \\
Mode & 132 & $126^{\mathrm{a}}$ & 23 & $20^{\mathrm{a}}$ \\
Std. Deviation & 15,630 & 17,495 & 7,616 & 7,047 \\
Skewness &,- 633 &, 005 &,- 600 &,- 732 \\
Std. Error of &, 337 &, 337 &, 337 &, 337 \\
Skewness & 1,267 &,- 128 &,- 862 &,- 574 \\
Kurtosis &, 662 &, 662 &, 662 &, 662 \\
Std. Error of & 79 & 80 & 26 & 24 \\
Kurtosis & 93 & 92 & 2 & 1 \\
Range & & &
\end{tabular}


Maximum

172

172

28

\section{Uji Persyaratan Data}

Uji persyaratan analisis data terdiri dari uji normalitas dan uji linieritas.

Tabel 2. Rekapitulasi Hasil Uji Normalitas

\begin{tabular}{|ll|r|r|r|r|}
\hline & & $\begin{array}{r}\text { Kemandiri } \\
\text { an_Belajar }\end{array}$ & $\begin{array}{c}\text { Minat_Ba } \\
\text { ca }\end{array}$ & $\begin{array}{c}\text { Kecerdasan } \\
\text { Naturalis }\end{array}$ & $\begin{array}{r}\text { Prestasi_Bel } \\
\text { ajar_Biologi }\end{array}$ \\
\hline $\mathrm{N}$ & Mean & 132,48 & 137,54 & 16,60 & 15,82 \\
Normal & Std. & 15,630 & 17,495 & 7,616 & 7,047 \\
Parameters & Deviation &, 147 &, 082 &, 153 &, 150 \\
Most & Absolute &, 096 &, 082 &, 083 &, 096 \\
Extreme & Positive &,- 147 &,- 060 &,- 153 &,- 150 \\
Differences & Negative & 1,041 &, 582 & 1,081 & 1,062 \\
Kolmogorov-Smirnov Z &, 229 &, 887 &, 193 &, 209 \\
Asymp. Sig. (2-tailed) & & &
\end{tabular}

a. Test distribution is Normal.

b. Calculated from data.

Berdasarkan tabel 2 maka dapat disimpulkan bahwa data dari ketiga variabel litian menunjukan semua sampel lebih besar dari nilai sig. 0,05 sehingga $\mathrm{H}_{0}$ ima. Dengan kata lain data dari semua sampel penelitian berdistribusi normal.

Tabel 3. Rekapitulasi Hasil Uji Linieritas

\begin{tabular}{|c|c|c|}
\hline Garis yang diuji & Sig. & Simpulan \\
\hline X1 terhadap Y & 0,212 & Model regresi berpola linier \\
\hline X2 terhadap Y & 0,070 & Model regresi berpola linier \\
\hline X3 terhadap Y & 0,178 & Model regresi berpola linier \\
\hline
\end{tabular}

Berdasarkan table 3 maka dapat disimpulkan bahwa data dari ketiga variabel penelitian menunjukan semua sampel lebih besar dari 0,05 sehingga $\mathrm{H}_{0}$ diterima. Dengan kata lain data dari semua model regresi yang diuji berpola linier.

Tabel 4. Rekapitulasi Hasil Uji Multikolinieritas

\begin{tabular}{|c|l|c|c|}
\hline \multicolumn{2}{|c|}{ Model } & \multicolumn{2}{c|}{ Collinearity Statistics } \\
\cline { 3 - 4 } 1 & Tolerance & VIF \\
\hline \multirow{2}{*}{1} & (Constant) & & \\
\cline { 2 - 4 } & Kemandirian_Belajar &, 251 & 3,985 \\
\cline { 2 - 4 } & Minat_Baca &, 352 & 2,841 \\
\hline & Kecerdasan_Naturalis &, 206 & 4,849 \\
\hline
\end{tabular}

a. Dependent Variable: Prestasi_Belajar_Biologi 
Berdasarkan tabel 4 ternyata nilai VIF lebih kecil dari 10 untuk semua variabel bebas. Dengan demikian, dapat disimpulkan bahwa antara variabel bebas kemandirian belajar $\left(\mathrm{X}_{1}\right)$, minat baca $(\mathrm{X} 2)$ dan kecerdasan naturalis $\left(\mathrm{X}_{3}\right)$ tidak terjadi multikolinieritas.

\section{Pengujian Hipotesis}

Tabel 5. HAsil Perhitungan Analisis Regresi

\section{Rekapitulasi Hasil Uji Koefisien Korelasi}

Model Summary

\begin{tabular}{|l|r|r|r|r|}
\hline $\begin{array}{l}\text { Mode } \\
1\end{array}$ & \multicolumn{1}{|c|}{ R } & R Square & Adjusted R Square & Std. Error of the Estimate \\
\hline 1 &, $957^{\mathrm{a}}$ &, 915 &, 909 & 2,120 \\
\hline
\end{tabular}

a. Predictors: (Constant), Kecerdasan_Naturalis, Minat_Baca, Kemandirian_Belaj

\section{Rekapitulasi Hasil Uji Signifikansi}

ANOVA ${ }^{\mathrm{a}}$

\begin{tabular}{|r|r|r|r|c|l|}
\hline Model & Sum of Squares & Df & Mean Square & F & Sig. \\
\hline \multirow{4}{*}{1 Regression } & 2226,626 & 3 & 742,209 & 165,132 &, $000^{\mathrm{b}}$ \\
Residual & 206,754 & 46 & 4,495 & & \\
Total & 2433,380 & 49 & & & \\
\hline
\end{tabular}

a. Dependent Variable: Prestasi Belajar Biologi

b. Predictors: (Constant), Kecerdasan_Naturalis, Minat_Baca, Kemandirian

Rekapitulasi Hasil Perhitungan Persamaan Garis Regresi

Coefficients $^{\text {a }}$

\begin{tabular}{|c|c|c|c|c|c|c|}
\hline \multirow{2}{*}{\multicolumn{2}{|c|}{ Model }} & \multicolumn{2}{|c|}{$\begin{array}{l}\text { Unstandardized } \\
\text { Coefficients }\end{array}$} & $\begin{array}{c}\text { Standardized } \\
\text { Coefficients }\end{array}$ & \multirow[t]{2}{*}{$\mathrm{T}$} & \multirow[t]{2}{*}{ Sig. } \\
\hline & & $\mathrm{B}$ & $\begin{array}{l}\text { Std. } \\
\text { Error }\end{array}$ & Beta & & \\
\hline \multirow{4}{*}{1} & (Constant) & $-27,586$ & 4,623 & & 5967 &, 000 \\
\hline & Kemandirian_Belajar & , 181 & ,039 & ,401 & 4,672 &, 000 \\
\hline & Minat_Baca &, 100 & ,029 & ,248 & 3,418 & 001 \\
\hline & Kecerdasan Naturalis & ,346 & 088 & ,374 & 3,952 & 000 \\
\hline
\end{tabular}

a. Dependent Variable: Prestasi_Belajar_Biologi

Koefisien korelasi ganda $\left(\mathrm{r}_{\mathrm{y} 123}\right)$ pada tabel 4.7 sebesar $0,957^{\mathrm{a}}$ lebih dari $\mathrm{r}_{\text {tabel }}$ sebesar 0,279 mempunyai makna bahwa hubungan kemandirian belajar $\left(\mathrm{X}_{1}\right)$, minat baca $\left(\mathrm{X}_{2}\right)$ dan kecerdasan logika $\left(\mathrm{X}_{3}\right)$ terhadap prestasi belajar biologi $(\mathrm{Y})$ sangat kuat. Sementara itu, koefisien determinasi $\left(\mathrm{r}^{2}{ }_{\mathrm{y} 123}\right)$ sebesar $=0,915$ mempunyai makna bahwa kemandirian belajar $\left(X_{1}\right)$, minat membaca $\left(X_{2}\right)$ dan kecerdasan naturalis $\left(\mathrm{X}_{3}\right)$ secara bersama-sama memberi pengaruh sebesar 91,5\% terhadap prestasi belajar biologi $(\mathrm{Y})$, sisanya $(8,5 \%)$ karena pengaruh faktor lain..Persamaan regresi ganda dari tabel 4.9 diperoleh $\widehat{Y}=-27,586+0,181 \mathrm{X}_{1}+$ $0,100 \mathrm{X}_{2}+0,346 \mathrm{X}_{3}$ yang berarti bahwa kenaikan satu skor kemandirian belajar 
$\left(\mathrm{X}_{1}\right)$, minat baca $\left(\mathrm{X}_{2}\right)$ dan kecerdasan naturalis $\left(\mathrm{X}_{3}\right)$ secara bersama-sama memberikan kenaikan sebesar 0,181 untuk $\mathrm{X}_{1}$, kenaikan 0,100 untuk $\mathrm{X}_{2}$ dan kenaikan 0,346 untuk untuk $\mathrm{X}_{3}$ terhadap skor prestasi belajar biologi (Y). Berdasarkan uji signifikan menunjukan bahwa nilai Sig. $=0,000<0,05$ dan $\mathbf{F}_{\text {hitung }}=165,132$. Hal ini menunjukan bahwa $\mathrm{H}_{\mathrm{o}}$ tidak dapat diterima, berarti $\mathrm{H}_{1}$ diterima. Artinya hipotesis penelitian dapat diterima. Sehingga dapat disimpulkan bahwa terdapat pengaruh yang signifikan kemandirian belajar, minat membaca dan kecerdasan naturalis secara bersama-sama terhadap prestasi belajar biologi.

Dari pengujian hipotesis variabel X1 menunjukan bahwa nilai $\mathbf{t}_{\text {hitung }}=$ 4,672 $>\mathbf{t}_{\text {tabel }}=1,68$ dan Sig. $=0,000<0,05$. Hal ini menunjukan bahwa Ho tidak dapat diterima, berarti H1 diterima. Artinya hipotesis penelitian dapat diterima. Sehingga dapat disimpulkan bahwa terdapat pengaruh yang signifikan kemandirian belajar terhadap prestasi belajar biologi. Dari pengujian hipotesis variabel X2 menunjukan bahwa nilai $\mathbf{t}_{\text {hitung }}=3,418>$ ttabel $=1,68$ dan $\boldsymbol{S i g} .=$ $0,001<0,05$. Hal ini menunjukan bahwa $\mathrm{H}_{\mathrm{o}}$ tidak dapat diterima, berarti $\mathrm{H}_{1}$ diterima. Sehingga hipotesis diterima dan dapat disimpulkan bahwa terdapat pengaruh yang signifikan minat baca terhadap prestasi belajar biologi. Dari pengujian hipotesis variabel $\mathrm{X} 3$ menunjukan bahwa nilai $\mathbf{t}_{\text {hitung }}=3,952>$ ttabel $=$ 1,68 dan Sig. $=0,000<0,05$. Hal ini menunjukan bahwa $H_{0}$ tidak dapat diterima, berarti $\mathrm{H}_{1}$ diterima. Artinya hipotesis penelitian dapat diterima. Sehingga dapat disimpulkan bahwa terdapat pengaruh yang signifikan kecerdasan naturalis terhadap prestasi belajar biologi.

\section{PEMBAHASAN}

Berdasarkan data tersebut di atas, dapat dikatakan bahwa apabila prestasi belajar biologi siswa ingin ditingkatkan secara optimal, maka perlu peningkatan kemandirian belajar siswa, minat baca siswa dan kecerdasan naturalis siswa yang baik. Dengan kemandirian belajar siswa, minat membaca siswa dan kecerdasan naturalis siswa yang baik akan dapat meningkatkan proses pembelajaran yang lebih baik yang berdampak pada peningkatan prestasi belajar biologi siswa yang baik pula.Berdasarkan hasil perhitungan di atas, maka hasil penelitian ini sejalan dengan pendapat Thursan Hakim (2007:56) mengatakan bahwa seseorang yang ingin meningkatkan prestasi belajarnya itu harus mampu menemukan faktor penghambat belajar dan mengatasi hambatan belajar secara bijak. Dalam hal ini yang dapat mengatasi hambatan belajar secara bijak adalah kemandirian belajar, minat baca dan kecerdasan naturalis memberikan pengaruh bersama-sama terhadap prestasi belajar biologi siswa SMA Negeri di Kecamatan Rangkasbitung.

Berdasarkan data di atas diketahui kemandirian belajar siswa memiliki pengaruh terhadap prestasi belajar biologi. Maka dapat dikatakan bahwa apabila prestasi belajar biologi siswa ingin ditingkatkan secara optimal, maka perlu peningkatan kemandirian siswa yang tinggi. Peningkatan kemadirian belajar siswa yang baik akan memberikan dorongan bagi siswa untuk prestasi belajar biologi. Berdasarkan hasil perhitungan di atas, maka hasil penelitian ini sejalan dengan pendapat Mutadin (2002:76) bahwa mengatakan kemandirian belajar adalah suatu sikap individu yang diperoleh secara kumulatif selama perkembangan, individu akan terus belajar untuk bersikap mandiri dalam menghadapi berbagai situasi lingkungan, sehingga individu pada akhirnya akan mampu berpikir dan bertindak sendiri. Dan ketika seseorang sudah menggunakan pikiran dengan baik dan atas 
kehendak sendiri, maka prestasi pun mudah diraih. Dalam hal ini dibuktikan yaitu dalam penelitian bahwa kemandirian belajar memberikan pengaruh terhadap prestasi belajar biologi siswa SMA Negeri di Kecamatan Rangkasbitung.

Berdasarkan data di atas diketahui minat baca siswa memiliki pengaruh terhadap prestasi belajar biologi. Maka dapat dikatakan bahwa apabila prestasi belajar biologi siswa ingin ditingkatkan secara optimal, maka perlu peningkatan minat membaca siswa yang tinggi. Peningkatan minat membaca siswa yang baik akan memberikan dorongan bagi siswa untuk prestasi belajar biologi. Berdasarkan hasil perhitungan di atas, maka hasil penelitian ini sejalan dengan pendapat Soedarso (2006:4) Minat baca merupakan aktivitas yang komplek dalam membaca meliputi pengertian dan khayalan, mengamati, serta mengingat-ingat. Membaca juga merupakan kemampuan dan keterampilan untuk membuat suatu penafsiran terhadap bahan yang dibaca. Yang dimaksud dengan kepandaian membaca tidak hanya menginterpretasikan huruf-huruf, gambar-gambar, dan angka-angka saja, tetapi yang lebih luas daripada itu adalah kemampuan seseorang untuk dapat memahami makna dari sesuatu yang dibacanya. Dalam proses membaca terlihat aspek-aspek berpikir seperti berikut: mengingat, memahami, membeda-bedakan, membandingkan, menemukan, menganalisis, mengorganisasikan dan pada akhirnya menerapkan apa-apa yang terkandung dalam bacaan. Jadi dalam membaca diperlukan intelektual yang tinggi. Selain itu membaca merupakan suatu bentuk komunikasi antara pembaca dan media cetak yang dibacanya sebagai wakil dari penulisnya. Dalam hal ini dijelaskan bahwa minat membaca memberikan pengaruh terhadap prestasi belajar biologi siswa SMA Negeri di Kecamatan Rangkasbitung.

Berdasarkan hasil perhitungan di atas, maka hasil penelitian ini sejalan dengan pendapat Soehardjo (1982:1) kecerdasan naturalis adalah kesanggupan, kecakapan dan kekuatan dari diri manusia yang digunakan untuk berfikir dalam ilmu pengetahuan entang fenomena alam dan spesies yang ada di dalamnya. Seseorang yang ingin meningkatkan prestasi belajarnya itu harus mampu menemukan faktor penghambat belajar dan mengatasi hambatan belajar secara bijak. Dalam hal ini yang dapat mengatasi hambatan belajar secara bijak yaitu dengan memiliki kecerdasan naturalis dengan baik, maka akan menghasilkan prestasi yang baik pula. Dalam hal ini telah dibuktikan bahwa kecerdasan naturalis memberikan pengaruh terhadap prestasi belajar biologi siswa SMA Negeri di Kecamatan Rangkasbitung.

\section{KESIMPULAN}

1. Terdapat pengaruh yang signifikan kemandirian belajar, minat baca dan kecerdasan naturalis secara bersama-sama terhadap prestasi belajar biologi siswa SMAN kecamatan Rangkasbitung.

2. Terdapat pengaruh yang signifikan kemandirian belajar terhadap prestasi belajar biologi siswa SMAN kecamatan Rangkasbitung.

3. Terdapat pengaruh yang signifikan minat baca terhadap prestasi belajar biologi siswa SMAN kecamatan Rangkasbitung.

4. Terdapat pengaruh yang signifikan kecerdasan naturalis terhadap prestasi belajar biologi siswa SMAN kecamatan Rangkasbitung. 


\section{SARAN}

Berdasarkan kesimpulan dikemukakan beberapa saran sebagai berikut:

1. Hendaknya para guru, para pengelola lembaga pendidikan, serta para orang tua senantiasa mendorong siswanya/putranya agar mereka mempunya kemandirian dalam belajar biologi berbagai cara agar siswa-siswinya mau berkonsentrasi, memahami dan melatih kemampuan terhadap materi yang diberikan, jadikan materi pelajaran (masalah disekitar kita) yang tadinya abstrak menjadi kenyataan; munculkan semangat belajar siswa untuk belajar secara mandiri, dan menghilangkan pragdima lama yakni pelajaran dan guru biologi selalu terkesan sulit dan membosankan.

2. Hendaknya para guru, para pengelola lembaga pendidikan, serta para orang tua senantiasa mengarahkan siswanya/putranya agar mereka mempunyai minat baca yang tinggi dan agar guru serta orang tua bisa memberikan bimbingan dan arahan sesuai yang dibutuhkan oleh siswa/putranya, sehingga siswa/putranya bisa belajar, berprestasi dan berkompetisi untuk meraih kesuksesan yang setinggi-tingginya.

3. Hendaknya para guru, para pengelola lembaga pendidikan, serta para orang tua senantiasa membimbing siswanya/putranya agar mereka mempunyai kecerdasan naturalis merupakan komponen yang memiliki andil signifikan terhadap keberhasilan belajar, banyak konsep dan teori biologi yang perlu dilatih dan dibiasakan melalui kecerdasan logika.

4. Hendaknya para guru dan para pengelola lembaga pendidikan bisa memadukan antara kemandirian belajar, minat baca dan kecerdasan naturalis dari para siswanya untuk meningkatkan prestasi belajar siswa, yang bermuara pada peningkatan kualitas pendidikan di sekolah.

\section{DAFTAR PUSTAKA}

Budiarto, E. 2004. Metodologi Penelitian. Jakarta: EGC.

Glaser, E. 2008. Critical Thinking Apasial-UK edition. London: Pearson Education.

Mutadin. Z. 2002. Kemandirian sebagai kebutuhan psikologi pada remaja. Jakarta: Bumi Aksara.

Soedarso. 2006. Sistem membaca cepat dan efektif. Jakarta: Gramedia Pustaka Utama.

Soehardjo, H. 1982. Belajar mengajar. Jakarta: P2LPTK.

Syakib, Ahmad. 2012. Pengaruh konsep diri, kemandirian Belajar dan Kecerdasan Logika terhadap prestasi belajar. Tesis, Jakarta: Unindra.

Tursan Hakim. 2007. Belajar Secara EFKTIF. Jakarta: Puspa Suara 